\title{
The value of education as a factor in the modelling of a successful career of Roma university graduates
}

Streszczenie: We współczesnym społeczeństwie sukces i jakość życia jednostki uzależnione są od zdobytego przez nią wykształcenia. Z licznych badań wynika, że właśnie deficyt niezbędnego poziomu wykształcenia należy do kluczowych czynników odpowiedzialnych za społeczne, a przede wszystkim ekonomiczne wykluczenie Romów. W ten sposób w dłuższej perspektywie system kształcenia jest niezwykle istotnym narzędziem służącym do ograniczenia skutków marginalizacji Romów i umożliwiającym wzrost ich szans na zaangażowanie społeczne. Systematyczne kroki wspierające kształcenie romskich dzieci oraz ich sukcesy w szkole budzą duże nadzieje, są również przedmiotem wielu wysiłków i pochłaniają znaczące środki finansowe. Artykuł powstał na podstawie projektu grantowego IGA SV60171706020 / 2110 Koncepcja wartości edukacyjnych z perspektywy uczniów z różnych środowisk kulturowych (Uniwersytet Tomasa Baty w Zlínie, Wydział Humanistyczny, Wydział Nauk Pedagogicznych, Republika Czeska). Autorka wykorzystuje częściowo wyniki realizowanego projektu, skupia się nie tylko na przyczynach szkolnych niepowodzeń romskich uczniów i studentów, ale głównie na czynnikach warunkujących pozytywną ścieżkę edukacyjną wyróżnionych grup. Przy wykorzystaniu metody rozmów narracyjnych z Romami z wyższym wykształceniem poszukuje ważnych momentów i specyficznych sytuacji, które przyczyniły się do uzyskania przez nich sukcesów edukacyjnych, ukoronowanych uzyskaniem absolutorium wyższej uczelni. Wyniki przeprowadzonych badań wskazują, iż aspiracje edukacyjne, jasno określone cele, wysoka pozycja edukacji w systemie wartości jednostki oraz własne możliwości i wysiłek są czynnikami determinującymi sukcesy szkolne romskich uczniów. Istotne są też rola wzorca grupy społecznej, jaką jest inteligencja romska, oraz postawa nauczyciela i jego kompetencje.

Słowa kluczowe: wartość, Romowie, student, sukcesy w szkole, droga do wykształcenia, uczeń, historia życia 


\section{Introduction}

During interviews with Roma parents and their children, in situations of social or educational character, we often encounter the problem of very low professional and educational self-confidence. Children from families with a low socio-economic status quite naturally reproduce the life paths of their parents, thus of course taking over their opinion that higher education and career are solely for the non-Roma. At the same time, we may reflect the fact that acknowledgement of the pursuit of higher education for one's future professional career grows in the eyes of the Roma. Likewise, their interest in other forms of adult education grows, too. We noted that adult members of the Roma population would now invest far more effort in their education than in the past. Unfortunately, the options of enrolling adults in the educational process are quite limited. For instance, to obtain an apprenticeship or graduation certificate is not at all simple for the Roma, to say the least, so that they have to make do with requalification courses offered by employment offices, or with other forms of adult education organized by various nonprofit (NGO) organizations. However, positive is the fact that some parents are beginning to realize their role in participating in the school education of their children as well as in practical involvement in preparing their children for their school lessons.

\section{The value of education as a determinant in the academic success or failure of Roma students}

Roma people are the largest ethnical minority living in the territory of the Czech Republic. According to qualified estimates of the coordinators for the issues concerning this minority, their number is 240,300 , i.e., $2.2 \%$ of the total population of the CR. It is estimated that as many as $50 \%$ of these Roma people are socially excluded or socially threatened by marginalization or ostracism (Report of the Status of the Roma Minority in the Czech Republic in 2017 and 2018, p. 4). Permanent and lifelong existence on the edge of the society is according to Lukáč (2015, p. 11) the principal cause of the low educational level amongst the Roma. The main objective therefore is to support the children from such families in their educational path and to engage relevant key instruments in the pursuit of this objective, such as integration or inclusion, as measures that can minimize the differences between children 
from excluded localities and other children. Nevertheless, despite all these efforts, children from Roma families remain less successful at the school, as many research studies indicate (GAC, 2007; GAC, 2009).

There are several obvious reasons and causes of the Roma students' lower rate of success in education, compared to students from the majority environment. As many publications agree, one of the principal factors of the Roma students' failure rate is their different socio-cultural environment, in which they grow up and are influenced by during the process of socialization (Gulová, 2010; GAC, 2007). Also, decision-making about further education is impacted by factors of rather subjective nature, such as disposition to motivation, attitude, aspiration, etc. However, even these subjective factors are influenced by their affiliation to a certain social stratum. It can be said that all strata of society place a relatively high emphasis on education, but the lower the social class, the lower the number of those who prefer education. According to the GAC (2009, p. 8) research studies, the causes of educational inequalities can be divided into two main groups:

1) Family

- material background of the family,

- the position of education as a value of preference,

- social and symbolical capital.

2) School

- strengthening or weakening disadvantage,

- on the part of the family, GAC (2009, p. 7-8) views the following mechanisms as the most important aspects of educational inequalities in:

- less developed cultural capital of the child's family,

- less stimulating environment language-wise,

- lower support for the child's development on the part of the family,

- absence of positive patterns,

- the family's lower material provisions and worse material conditions.

Perception of education as a value in an environment where the individual is living, as well as interiorization of the importance and significance of education as a value in the structure of the individual's personality is part of the cultural capital of the individual, family, descent and society, mutually shared and formed over generations. Moreover, it is part of his life style, career, orientation on values, etc. If this value is not included in the hierarchy of the family's ladder of values which represent a certain culture, and if the individual does not attribute at least a certain value to it, it is difficult 
to influence the individual during his upbringing and education at school. The absence of this value or a lower position of this value in the individual's system of preferences impact negatively on his educational and professional trajectory. The importance and the role of the values that a child brings to his school indicate the environment that the child comes from and impacts significantly on his understanding of the role of education in the society (Sak, 2000; Katrňák, 2003; Staňková, Venterová, 2017).

According to Brüggemann (2012, p. 50), marginalization in the education of Roma people is closely related to low level of aspiration and their attitude arising from their belief that higher education is perceived as undesirable by the Roma minority that fears losing a certain form of cultural identity and therefore a priori rejects the notion of higher education. In this case, culture is the primary factor causing the low educational aspiration of Roma students, especially girls who prefer traditional Roma values. Nevertheless, a research report issued by UNDP/World Bank/EC Regional Roma Survey (Brüggemann, 2012, p. 50) claims that even though the existence of differences has been confirmed, scholar have not concluded that the level of aspiration is directly related to a concrete culture or ethnic origin. The results of research studies that focus on the perception of the value of education in this specific group are somewhat ambivalent. On the one hand, they state that the Roma do not view education as a value and, on the other, they say that even though the Roma minority perceives education, from the axiological perspective, entirely differently than the majority society and usually put education on a lower level of values, it cannot be absolutely stated that the Roma do not view education as a value (Kaleja, Krpec, 2013). Nevertheless, based on our own research conducted in 2017 on a sample of Roma pupils (Staňková, Venterová, 2017), we may say that the key preferences of values do not differ from those of the majority. The results indicate that, compared with the students in the majority population, the Roma pupils do ascribe to education a lower position in the hierarchy of values, but do not put it on the lowest position. As far as a comprehensive comparison of value preferences is concerned, we may state that the value systems of Roma pupils and those of the majority population are very similar. Roma pupils give preference to such values as health, love, happy family and children, while giving less preference to life in peace, interesting work, God (faith), personality development, the environment and usefulness to others (Staňková, Venterová, 2017).

During our research, we focused on following the educational trajectory of successful Roma students, especially those who achieved tertiary educa- 
tion. We concentrated on a different point of view, namely, on the aspects that can be used as an example and model for others to follow. We searched for the positive factors that modeled their career. Furthermore, we tried to identify the position that education has in the preferences of university-educated Roma, as they told us in their own words.

\section{Methods}

Due to the character of the issues under study and thanks our effort to grasp the uniqueness of meanings and moments on the subjective level, we adopted a qualitative approach to the research reality and chose the method of narrative analysis, where the researcher concentrates on the stories of individual real events and on uncovering the sense and meaning of "things "and the "stories" narrated by each individual. The technique of data collection during narrative interviews aims to attaining the outlined objective. "During a narrative interview, the subject is not confronted by standardized questions instead, he is encouraged to speak freely using his own words" (Hendl, 2005, p. 176). Contrary to a normal conversation, a narrative interview includes several questions asked by the researcher, while putting emphasis on the studied person's long narration, with the advantage of the narrator's natural and spontaneous testimony. The researcher furthers the narration by making room by means of narrative impulses - encouragement to storytelling. The research also provides rich material for analysis, but considerable willingness and collaboration is expected on the part of the informant.

\section{Research questions}

The main objective of the research is to capture the important momenta and specifics of the stories told by university-educated Roma students and to identify the role the perception of the value of education played in their successful educational trajectory.

The main research questions were defined as follows:

What are the important moments and specifics in the stories of university-educated Roma and what is the role that the perception of the value of education played in their successful educational trajectory? 


\section{Research sample}

The basic criteria on the research sample were:

- university education (at least a bachelor degree)

- declared affiliation to Roma ethnicity

- completed tertiary education in no more than 2 preceding years ${ }^{1}$.

Another necessary criterion for our research was the willingness of the informants to share their story about their educational career, their own impressions, and their own experiences. The final research sample counted 6 informants ( 3 women and 3 men):

Table 1. List of informants

\begin{tabular}{|l|l|l|l|}
\hline Informant: & $\begin{array}{c}\text { Highest education } \\
\text { reached, year } \\
\text { of graduation: }\end{array}$ & \multicolumn{1}{|c|}{ Program or field of study: } & \multicolumn{1}{|c|}{ Employment / study: } \\
\hline 1. & Univ. (B.C.), 2017 & Sociology & Career consultant /field worker \\
\hline 2. & Univ. (B.C.), 2017 & Charity and social work & $\begin{array}{l}\text { University student (or Mgr.), Field: } \\
\text { Management in social services }\end{array}$ \\
\hline 3. & Univ. (M.A.), 2016 & Social work and consultancy & $\begin{array}{l}\text { Cultural pedagogy/museum pedago- } \\
\text { gue }\end{array}$ \\
\hline 5. & Univ. (B.C.), 2017 & $\begin{array}{l}\text { Teaching of basic sociological } \\
\text { sciences and health education }\end{array}$ & Assistant pedagogue \\
\hline 4. & Univ. (B.C.), 2017 & Charity and social work & $\begin{array}{l}\text { University student (Master), Field: } \\
\text { Management in social services } \\
\text { Social worker in low-threshold facility }\end{array}$ \\
\hline 6. & Univ. (Ing./M.S.), 2018 & $\begin{array}{l}\text { Computer visualization and } \\
\text { digital images }\end{array}$ & Junior consultant \\
\hline
\end{tabular}

Source: Own research.

\section{Data analysis}

The whole narrative interview was recorded with the informant's consent and then transcribed. For the purposes of the analysis, we obtained a rough transcript. We proceeded according to the methodology of narrative research as described by Čermák, Hiles, Chrz (2007) following 15 years of development. The NOI model (Narrative Oriented Inquiry), derives from a psychologically oriented approach to narrative research as a conception of narrative

1 This time-determined criterion of completion of studies was chosen intentionally as it enabled the informants to describe their educational career as a "fresh theme" in their memory. 
analysis of data obtained with the aid of narrative interviews. In accordance with the objectives of our research, we concentrated on the contents, rather than the formal aspects of the text - thus, we proceeded according to the mode of narrative analysis of the holistic content and categorial content. On the one hand, we were interested in the individual stories as such, but also by the common characteristics that were noted in all the stories, on the other.

\section{Findings}

Based on the analysis of the data in the narrative interviews, we were able to capture the elements of positive effects involved in the formation of our informants' successful career. It is necessary to mention that these elements were summarized on the basis of a qualitative approach to the issue under study. Hence, they are very individual and are defined in the perspective of one's own perception of reality and the experiences of the actors who took part in the research.

Table 2. Important elements modeling the educational career of university-educated Roma

\begin{tabular}{|l|}
\hline Determinant Factors and Specifics \\
\hline FAMILY ENVIRONMENT \\
Encouraging and favorable family environment \\
Education or profession of the parents/grandparents \\
Residing outside segregated Roma locality \\
Strong influence of the mother \\
Constellation of siblings - only child or first-born child \\
Individual events \\
\hline SCHOOL ENVIRONMENT \\
Positive influence of teachers \\
Financial support and Roma scholarships \\
Individual events \\
\hline SURROUNDING SOCIETY \\
Important influence of certain persons \\
Individual events \\
\hline PERSONAL SPECIFICS \\
Clearly outlined goals and educational aspirations \\
\hline High position of education in the system of values \\
\hline Capabilities and own effort \\
Coming to terms with one's ethnic identity \\
\hline
\end{tabular}

Source: Own research. 


\section{Family environment}

Quite naturally, this environment is determining for the formation of the life (as well as educational) career of individuals, as it is the primary place of socialization and cultural integration. We want to learn about the elements that impact on the future life of the persons under study, as described or emphasized in their stories. Analogically, we were able to find elements of a favorable and supportive family environment in all of the stories. The only difference was the degree and intensity of the descriptions. The informants referred to the environment where they had grown up as encouraging, positive, and inspiring - in short, as a pleasant place in their memory. In general, they defined their family environment very positively, almost idyllically. They praised favorable material and economic conditions in the family, positive mode of upbringing on the part of their parents and grandparents, common experiences, and functional relationships. Informants' home outside a segregated or socially excluded locality (at least according to the main protagonists' definition and description), i.e., a typical Roma locality, was recorded only in one case. Nearly all of the stories emphasized positively the role of the mother, her method of upbringing and care as positive and effective, both in terms of forming the children's personality and positive impact on their educational career and in terms of active and practical engagement in family-pupil-school relations. Quite interesting was also the fact that the participants in the research were either an "only-child" (4 out of 6 cases) or "first-born" - the elder of two siblings (1 case). Moreover, surprising is the fact that in 5 out of 6 cases the families where the informants has grown up spoke practically no Roma language - either the parents (hence also the children) were not using it at all, or did not even know the language. This leads us to question as to how important was the role of the Czech as native language in the successful start of enrollment in the educational system. One half of the informants maintained relations with their contemporaries and friends from the Roma environment. Likewise, one half of them had no close friends in that environment - all their friends were of non-Roma descent. The informant's appear to indicate that his factor had no particular impact on their educational career. As to the elements that impacted positively or negatively on the life of the persons under study, thus influencing their and educational career to certain degree, were very individual and specific. For instance, the absence or death of their father and the circumstances arising 
therefrom. However, such events seem not to have had a decisive positive or negative effect on the formation of the persons under study.

\section{School environment}

A dominant role in the school environment described in the informants' stories is attributed to positive descriptions (not always) of the influence of teachers, whereby we may call at least their positive effect as encouraging or motivating for their educational career. This element was emphasized by 5 participants. In some cases, their influence was so strong as to be defined as one of the key incentives in their educational career or formation of their professional profiling. Financial support in the form of Roma scholarships (or other support) as a positive invention into the educational career was acknowledged by 4 persons, thereof 3 claimed that they would not have been able to study without it or stated that it would have been unbearably hard for their parents.

Nevertheless, two of our participants in the research of the school environment claimed very negative experiences with xenophobic attitudes on the part of their schoolmates. Their descriptions indicate that this experience left a deep mark in their hearts and impacted unpleasantly on their educational process. On the other hand, however, we could also record considerable efforts on the part of the participants to handle these situations and find ways of adaptation and behavioral strategy as well mechanisms to prevent reoccurrence of such situations.

\section{Surrounding society}

Very strong impact of the external environment was recorded above all in the case of two informants. In both cases, we may speak of a decisive intervention into their educational career. They only differ in the timing of this impact. In the first case, the external impact of a certain person was instrumental in the restarting of an already terminated educational career, whereas in the second case, the external person's impact occurred at the very end of the informant's educational career, but was equally important. 


\section{Personal specifics}

\section{Clearly outlined life goals and educational aspirations}

These elements were dominant in the informants' stories and we could follow them throughout all their narrations. The participants have formulated their aspirations, goals, and desires quite clearly and many of them were aware of them strongly from their childhood or during their attendance of elementary schools. In this respect, the desire to pursue one's goals is so important that they did not hesitate to devote great effort and even sacrifices. In some cases, their aspirations were corroborated by the aspirations of their parents, teachers, or other persons.

\section{High position of education in the system of values}

The preceding theme is closely related to the relations and attitudes of the persons under study, such as character features, attitudes, models, ideals, values, and orientation of values. We have not encountered direct defining of value preferences in the stories, except for one the female informants who emphasized "health as being in the first place". She also disagreed with choosing to leave the educational system (high school) prematurely as some of her contemporaries and friends (Roma girls) due to establishing a family, i.e., the most preferred value in the Roma culture. However, it allowed us to realize the facts (values) that individual Roma prefer and let dominate their behavior. In summary, we may say that we could observe their attitudes to the school, as well attitudes to the society, etc., as a cognitive component of their behavioral pattern and life strategies. In all of the stories, however, it was apparent that the value of education was placed very high in the informants' ladder of values. Quite evidently, they became aware (often from the early days of their school attendance) of the importance of education for their future professional life.

The typical personal features associated with education that we identified were: purposefulness, responsibility, independence, perseverance, and ambitiousness.

\section{Capabilities and personal effort}

We could observe this element, too, in all the stories, as it was quite influential in this combination in the educational success of the individuals. We were able to follow the weight of individual values, as well as the role of individual components in pairs. Where capabilities were not sufficient for demanding studies, the deficit could be balanced by effort. On the other hand, we were able to record excellent academic proficiency and talent for concrete subjects. 


\section{Coming to terms with one's ethnic identity}

All of the participants have openly declared their affiliation to the Roma ethnicity. They referred to themselves as Roma people. However, were observed that their acceptance of the concept of their own ethnicity (as presented in their stories) was not always simple. They strongly commented about certain dilemmas in this respect - we noted them in four out of six persons. Most of the participants distanced themselves from the Roma ethnicity with respect to the "typical" (using their own words) images of the Roma people, e.g., negative behavior, bad social and economic environment (to the extent of pathology), and other negative specific symptoms. With respect to their own ethnic identity, they used expressions like "assimilated' or different Roma man/woman/people, i.e., different from other Roma, and similar expressions, in which they emphasized their differences from the stereotypes. In their stories, however, we noted a positive reconciliation with their own ethnic identity.

In the account of the above elements, we have intentionally avoided categorization of the individual elements by degree of importance or by the degree of their impact on the participants' educational career, because was ever since the beginning conceived and approached in a manner that precluded the possibility of differentiating such characteristics. The degree of the influence of the elements is very individual and specific in each of the stories. Moreover, it is presented from the given informant's real experience, so that the objective degree of the impact of the individual factors in the whole spectrum of causes, circumstances, and conditions is nearly impossible to measure.

\section{Discussion}

Our results correspond with the results of similar studies, both quantitatively and qualitatively oriented (comp. Fónadová, 2014; GAC 2007, 2009, ea.). In our opinion, the element of non-proficiency or non-use of the Roma language in the families of our informants, confirms the notion that in cases involving the use of a different mother language this deficit ought to be straightened out before enrolment in the first grade. The element of nonexisting friendships with one's contemporaries from the Roma environment may point out the importance of more dominant social relations with members of the majority population, hence also the possibility of focusing the family's orientation on the majority or intentional diversion of the family 
from "typical and stereotype" Roma as "problematic, inadaptable, and living from welfare benefits", or from the Roma ethnicity altogether. we could, however, simultaneously refer to the fact that ties to the Roma environment do not necessarily impact negatively on the educational career of individuals, as was noted in one of the testimonies. Naturally, a strong formative influence in the school environment is the positive impact of teachers. Teachers play a major role in the process of educating Roma pupils. Teachers not only mediate skills and knowledge, they also act as motivators and stimulators. Great emphasis is therefore put on his competence, primarily competence in pedagogic, social, prosocial, communicative activities. Furthermore, our research findings demonstrate how important is financial support to high school and university Roma students (in the form of scholarships or other subsidies). Moreover, some specialists (e.g., Hajská, 2005; Balvín, 2004) claim that financial support is determining for improvement of the educational options of those who would otherwise not be able to study due to unfavorable socioeconomic conditions in the family.

In any case, the factors very strongly determine the educational career of individuals are, above all, strong educational aspirations, clearly defined goals, high position of education in the individual's system of values and, of course, one's own capabilities and effort.

We aim to draw attention to these problems from the perspective of the Roma themselves, as they have experienced the impact of these problems "on their own skin" during the individual stages of the educational process. Rather than quantifying data obtained through anonymous investigation (which, naturally, can be the intent of the research), it is more constructive to analyze concrete lives, experiences, and experienced reality of those managed to handle the challenges and reach their targets.

\section{Acknowledgment}

This article was based on the grant project IGA SV60171706020/2110 The concept of educational values from the perspective of pupils from different cultural backgrounds (Tomas Bata University in Zlín, Faculty of Humanities, Department of Pedagogical Sciences, Czech Republic). However, any mistakes that remain are my own. 


\section{Bibliography}

Balvín, J. 2004. Výchova a vzdělávání romských žáků jako pedagogický systém. Praha: Radix.

Brüggemann, Ch. 2012. Roma Education in Comparative Perspective. Findings from the UNDP/World Bank/EC Regional Roma Survey. Roma Inclusion Working Papers. Bratislava: UNDP.

Čermák, I., Hiles D. i Chrz, V. 2007. Narativně orientovaný výzkum: interpretační perspektivy. In: Ǩehan, V. i Šucha, M. eds. Sborník z konference Kvalitativní prístup a metody ve vědách o člověku VI. Psychologica 37, Olomouc, Univerzita Palackého, ss. 53-66. https://is.muni.cz/el/1423/ podzim2008/PSY401/um/NOI_analyza_2.pdf.

Fónadová, L. 2004. Nenechali se vyloučit: sociální vzestupy Romů v české společnosti: (kvalitativní studie). Brno: Masarykova univerzita.

GABAL ANALYSIS \& CONSULTING. 2007. Závěrečná zpráva výzkumného projektu Analýza postoju a vzdělávacích potřeb romských dětí a mládeže. Praha: GAC. http://www.gac.cz/userfiles/File/nase_prace_vystupy/GAC_ ROMSKOLY_analyza_vzdelavacich_potreb_romskych_deti_FINAL.pdf?l angSEO=documents\&parentSEO=nase_prace_vystupy\&midSEO=GAC_ ROMSKOLY_analyza_vzdelavacich_potreb_romskych_deti_FINAL.pdf

GABAL ANALYSIS \& CONSULTING. 2009. Vzdělanostní dráhy a vzdělanostni šance romských žákyň a žáků základních škol v okolí vyloučených romských lokalit. Praha: GAC. http://www.vyzkum-mladez.cz/cs/registr/ vyzkumy/172-vzdelanostni-drahy-a-vzdelanostni-sance-.html.

Gulová, L. 2010. Analýza vzdělávacích potřeb romských žáků. Brno: PdF MU. Hajská, M. 2005. Romové v českém vzdělávacím systému. Praha: Polis. http:// epolis.cz/download/pdf/materials_53_1.pdf.

Hendl, J. 2005. Kvalitativní výzkum: základní metody a aplikace. Praha: Portál.

Kaleja, M. i Krpec, R. 2013. Kvantitativní analýza názorů a postojů romských žáků ke vzdělávání. https://www.researchgate.net/publication/311718689_ Kvantitativni_analyza_nazoru_a_postoju_romskych_zaku_ke_vzdelavani

Katrňák, T. 2003. Sociální a kulturní reprodukce společnosti v teoretické perspektivě. Bratislava: Sociologický ústav SAV, roč. 35, č. 1, ss. 61-76.

Lukáč, M. 2015. Romovia a vzdelanie. Sociálne a edukačné kontexty. Prešov: Vydavatelstvo Prešovskej univerzity.

Sak, P. 2000. Proměny české mládeže: česká mládež v pohledu sociologických výzkumů. Praha: Petrklíč. 
Staňková, I. i Venterová, L. 2017. Pojetí hodnoty vzdělání prizmatem žáků $z$ odlišného kulturního prostředí. In: Wiegerová, A. Dalajková, A. eds. Fórum mladých výzkumníků V. Zlín: Univerzita Tomáše Bati, Fakulta humanitních studií, ss. 27-37.

VLÁDA ČR. 2018. Zpráva o stavu romské menšiny za rok 2017. Praha: Úřad vlády České republiky, Sekce pro lidská práva, Oddělení kanceláře Rady vlády pro záležitosti romské menšiny a sekretariátu Rady vlády pro národnostní menšiny.

\title{
The value of education as a factor in the modelling of a successful career of Roma university graduates
}

\begin{abstract}
Good and successful life of each individual in contemporary society depends greatly on the level of completed education. Many research studies show that deficit of adequate education is one of the main factors of social and above all economic exclusion of the Roma population. Thus, in the long-term perspective, the educational system is the most important instrument that mitigates the negative impact of the marginalization of the Roma people and facilitates elevation of their social status. Systematic measures supporting the education of Roma children and their success in the school go hand in hand with the expectations arising from the great efforts and considerable financial means invested towards this objective.

In this study, however, we do not concentrate on defining the causes of the Roma students' academic failure. On the contrary, we view the issue from the opposite viewpoint, namely, from the perspective of the factors that have a positive influence on their educational trajectory. Using the method of narrative interviews with university-educated Roma students, we tried to identify the important moments and specifics that contributed to the formation of their successful educational careers leading to university graduation. Thus, the resulting findings help us understand the problem issues from a positive angle and emphasize the role of individual determinants for assurance of Roma students' success, as well as for serving as an example to Roma intelligence in general.
\end{abstract}

Keywords: value, Roma, student, academic success, educational career, learner, life story 